\title{
FLEXURAL AND SHEAR BEHAVIOUR OF REINFORCED CONCRETE SLAB WITH PVC PIPE AS A CAVITY FORMING IN TWO-WAY SYSTEM
}

\author{
Wahyu Mahendra Trias Atmadja ${ }^{1}$ | Herman Parung*2 | Rita Irmawaty ${ }^{2}$ | Arwin Amiruddin ${ }^{2}$
}

\footnotetext{
${ }^{1}$ Doctoral Program in Civil Engineering Department, Hasanuddin University, Makassar, Indonesia

${ }^{2}$ Department of Civil Engineering, Hasanuddin University, Makassar, Indonesia
}

\section{Correspondence}

*Herman Parung, Dept of Civil Engineering, Hasanuddin University, Makassar, Indonesia. Email: parungherman@yahoo.co.id

\section{Present Address}

Civil Engineering Department, Hasanuddin University Jl. Poros Malino Km 06 Bontomarannu, Gowa, South Sulawesi, Indonesia

\begin{abstract}
Piping modifications Polyvinyl Chloride as forming a hollow cavity in the concrete slab is one alternative to reduce the self-weight of structure. The placement of PVC pipe that has been modified on the concrete tensile area is expected not to reduce the bending strength of the plate. In the study, the analysis was compared to reinforced concrete slab massive (PB-1) with a hollow reinforced concrete slab PVC (PB-2) with the same thickness and compared well with hollow reinforced concrete slab PVC (PB-3) with an equal volume of the concrete slab massive reinforced (PB-1). All test objects have the same dimensions, including the number and spacing of reinforcement. The analysis method of the moment coefficient obtained flexural strength of PB-1 amounted to $328.175 \mathrm{kN}$, plate PB-2 amounted to $329.624 \mathrm{kN}$, and the plate of PB-3 amounted to $387.184 \mathrm{kN}$. While the results of the analysis using the Navier method deflections values obtained for the plate PB-1, PB-2, and PB-3 are 0.0948 $\mathrm{mm}, 0.33952 \mathrm{~mm}$, and $0.04267 \mathrm{~mm}$, respectively. Shear forces values for plate PB-1, PB-2 and PB-3 is $965.908 \mathrm{kN}, 231.818 \mathrm{kN}$ and $281.429 \mathrm{kN}$ respectively.
\end{abstract}

\section{KEYWORDS:}

Cavity Forming, Flexural and Shear Strength, PVC Hollow Slab, Reinforced Concrete Slab

\section{1 | INTRODUCTION}

To improve the efficiency of the reinforced concrete slab structure, emerging alternative technologies such as reinforced concrete hollow sphere slab. This technology aims to reduce the self-weight of structure and can save the concrete material. The reinforced concrete slab has been patented hollow ball called Bubble Deck plate with a minimum thickness of $23 \mathrm{~cm}$, and it's generally used for the flat plate with semi-precast system ${ }^{[1]}$. Aldejohann and Schenellenbach-Held ${ }^{[2]}$ mention, in general, the Bubble Deck has the same bending behavior as a solid concrete slab ${ }^{3}$. Comparisons between the two can be seen in Table 1 The main 
TABLE 1 Comparison of bubble deck with plates reinforced concrete solid.

\begin{tabular}{lrrc}
\hline$\%$ Solid Deck & $\begin{array}{c}\text { Same } \\
\text { Strength }\end{array}$ & $\begin{array}{c}\text { Same } \\
\text { Bending } \\
\text { Stiffness }\end{array}$ & $\begin{array}{c}\text { Same } \\
\text { Concrete } \\
\text { Volume }\end{array}$ \\
\hline Strength & 100 & 105 & 150 \\
Bending Stiffness & 87 & 100 & 300 \\
Volume of Concrete & 66 & 69 & 100 \\
\hline
\end{tabular}

TABLE 2 The load capacity plate experiment.

\begin{tabular}{|c|c|c|c|c|c|c|}
\hline \multirow[t]{2}{*}{ Specimen } & \multirow{2}{*}{$\begin{array}{c}\text { Dimension } \\
(\mathbf{m m})\end{array}$} & \multirow{2}{*}{$\begin{array}{r}\text { Concrete Volume } \\
(\%)\end{array}$} & \multicolumn{2}{|c|}{ Initial Crack Load } & \multicolumn{2}{|c|}{ Maximum Load } \\
\hline & & & Load $(k N)$ & $(\%)$ & Load $(k N)$ & $(\%)$ \\
\hline PL-1 & $2200 \times 1100 \times 120$ & 100 & 21.29 & 100 & 43.29 & 100 \\
\hline PL-2 & $2200 \times 1100 \times 120$ & 83 & & 53 & 46.29 & 107 \\
\hline PL-3 & $2200 \times 1100 \times 143$ & 100 & 15.29 & 72 & 68.29 & 158 \\
\hline
\end{tabular}

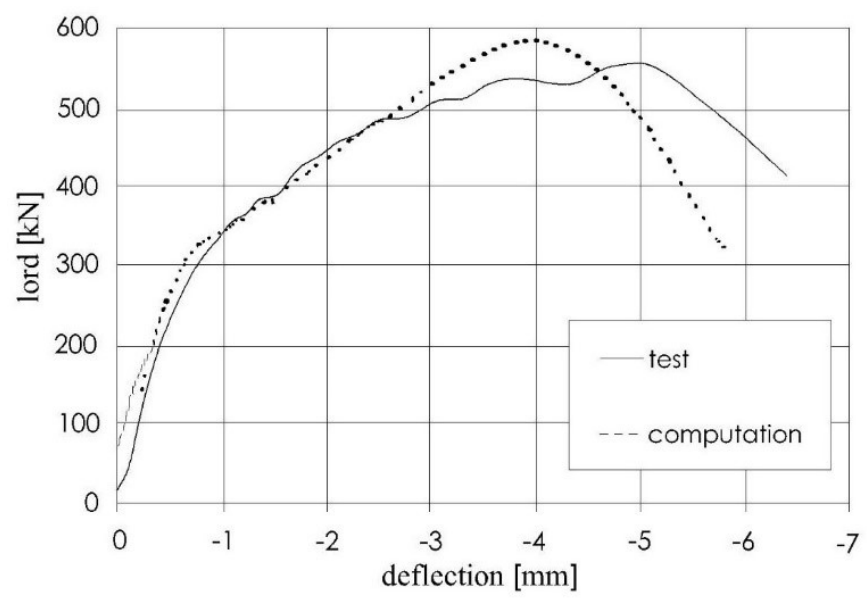

FIGURE 1 The load deflection.

difference between the Bubble Deck with a solid plate is resistance to shear, where the distance between the ball2 determines shear strength analysis in DIN 1045-1 hollow plate $(-)$.

Soeharno ${ }^{[4]}$ was testing their resilient experimentally against reinforced concrete slab hollow ball with a thickness of $12 \mathrm{~cm}$, with a one-way system and the cast in-situ system. Plate bending capacity is obtained as shown in Table $2{ }^{44}$.

Schnellenbach-Held and Pfeffer ${ }^{[5]}$ modeled the Bubble-Deck failure mechanisms due to the shear forces in the column area with punching test. The study was conducted through experimental and numerical. They were testing numerically using the finite element software non-linear DIANA. Reinforcement modeled appendage embedded assuming perfect bond between concrete and reinforcing steel material. Experimental and numerical comparison can be seen in Figure 1

An objective analysis of this study was to determine and compare flexural strength, shear strength, and deflection due to uneven loading on a reinforced concrete slab solid. The expected benefits of this analysis are the presence of cavities on a reinforced concrete slab to be obtained by saving the use of concrete and plates lighter, or the same volume of the concrete slab would have a greater effective height. 


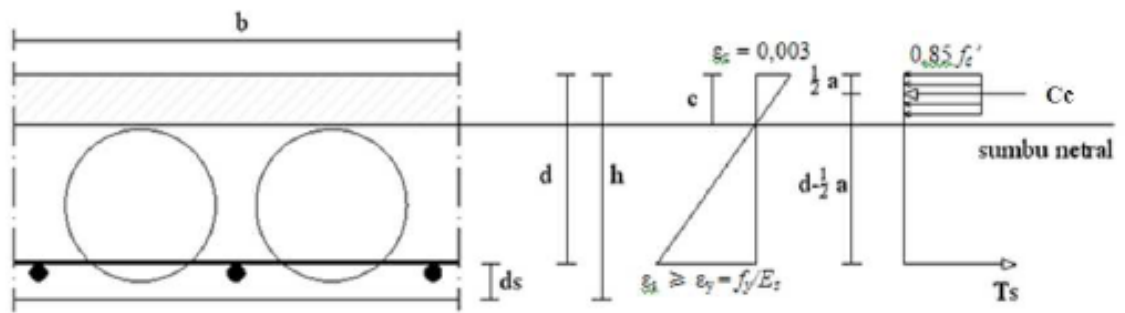

FIGURE 2 Stress and strain diagram of sectional hollow plate.

\section{2 | RELATED WORKS}

The distribution of stress and strain in the reinforced concrete slab in a balanced state, the compressive force on concrete $(\mathrm{Cc})$ would be balanced by the tensile strength of steel reinforcement (Ts). The distribution of stress and strain in the plate crosssection hollow balls can be seen in Figure 2. The condition of the steel reinforcement has undergone melting $\left(f_{c}=f_{y}\right)$ that applies Eq. 1

$$
C c=T s
$$

In the steel (Es) strain $=2.105 \mathrm{Mpa}$ and the compressive strength of concrete $f_{c}^{\prime} \leq 30 \mathrm{Mpa}$, then the nominal moment sectional calculated using Eq.2 as follows.

$$
M a=T s\left(d-\frac{1}{2} a\right)=C c\left(d-\frac{1}{2} a\right)=0.85 f_{c}^{\prime} b a\left(d-\frac{1}{2} a\right)
$$

Methods of Navier can analyze the analysis of two-way plate flexural strength. In the method of moment coefficient sought short spa direction torque value $\left(M_{l x}\right)$ and the moment the direction of long span $\left(M_{l y}\right)$ at the plate in both directions at the moment coefficient method according to Eq. 3

$$
M_{l x}=0.001 C_{x} w L_{x}^{2}
$$

Navier method using multiple sine Fourier series. Navier method for joint support plate with all four sides and pattern load is uniformly distributed load po ${ }^{6}$ is as follows.

Deflection equations for uniform loading pattern are:

$$
\Delta h=\frac{16_{p o}}{m^{6} D} \Sigma_{m=1}^{i} \Sigma_{n=1}^{i} \frac{\sin \frac{m \pi x}{a} \sin \frac{n \pi y}{b}}{m n\left[\frac{m^{2}}{a}+\frac{n^{2}}{b}\right]^{2}}
$$

Moment equation is the short span direction is:

$$
M_{x}=\frac{16_{p o}}{m^{4}} \Sigma_{m=1}^{i} \Sigma_{n=1}^{i} \frac{\frac{m}{a}^{2}+v \frac{n^{2}}{b}}{m n\left[\frac{m^{2}}{a}+\frac{n^{2}}{b}\right]^{2}} \sin \frac{m \pi x}{a} \sin \frac{n \pi y}{b}
$$

Navier ductility factor for hollow plate is :

$$
D=\frac{E h^{3}}{12\left(1-v^{2}\right)} \times \frac{I_{\text {berongga }}}{I_{\text {solid }}}
$$


TABLE 3 The detail of specimen.

\begin{tabular}{|c|c|c|c|c|c|c|}
\hline \multirow[t]{2}{*}{ \# } & \multirow{2}{*}{$\begin{array}{l}\text { Dimension } \\
(p \times l \times t)(\mathrm{mm})\end{array}$} & \multirow{2}{*}{$\begin{array}{l}\text { Diameter of } \\
\text { PVC }(\mathbf{m m})\end{array}$} & \multirow{2}{*}{$\begin{array}{c}\text { Distance } \\
\text { Between } \\
\text { PVC }(\mathbf{m m}) \\
\end{array}$} & \multicolumn{2}{|c|}{ Reinforcement Distance } & \multirow{2}{*}{$\begin{array}{l}\text { \#Test } \\
\text { Object }\end{array}$} \\
\hline & & & & $x \underset{(\mathbf{m m})}{x \text { direction }}$ & $\underset{(\mathrm{mm})}{y \text { direction }}$ & \\
\hline 1. & $2700 \times 1800$ & & & 100 & 100 & 1 \\
\hline 2. & $2700 \times 1800 \times 140$ & 76 & 24 & 100 & 100 & 1 \\
\hline 3. & $2700 \times 1800 \times 159$ & 76 & 24 & 100 & 100 & 1 \\
\hline
\end{tabular}

TABLE 4 The comparison volume of the plate.

\begin{tabular}{|c|c|c|c|c|c|c|c|}
\hline Specimen & $\begin{array}{c}\text { Plate Dimension } \\
(\mathbf{m m})\end{array}$ & $\begin{array}{c}\varnothing \text { Hollow } \\
(\mathbf{m m})\end{array}$ & $\begin{array}{c}\text { Distance Between } \\
\text { Hollow (mm) }\end{array}$ & $\begin{array}{l}\text { Dead Load } \\
\text { per } 1 \mathrm{~m}^{2}\end{array}$ & $\rho(\%)$ & $d(\mathbf{m m})$ & $\begin{array}{r}\text { Concrete } \\
\text { Volume }\end{array}$ \\
\hline PB-1 & $2700 \times 1800 \times 140$ & 5 & - & 315.663 & 0.403 & 112.4 & $100.00 \%$ \\
\hline PB-2 & $2700 \times 1800 \times 140$ & 76 & 24 & 273.540 & 0.403 & 112.4 & $86.33 \%$ \\
\hline PB-3 & $2700 \times 1800 \times 159$ & 76 & 24 & 315.663 & 0.345 & 131.4 & $100.00 \%$ \\
\hline
\end{tabular}

Expenses cracks that occur in reinforced concrete structures can be classified into two main categories, namely cracks caused due to external loads such as flexural cracks and shear cracks. Calculation of two-way capabilities of the pre-stressed plate in resisting the shear force is taken from the small value of the following equations as follows.

$$
\begin{gathered}
V c=0.17\left(1+\frac{2}{\beta}\right) \lambda \sqrt{f_{c}} b_{o} d \\
V c=0.083\left(\frac{\alpha_{s d}}{b_{o}}+2\right) \lambda \sqrt{f_{c}} b_{o} d \\
V c=0.33 \lambda \sqrt{f_{c}^{\prime}} b_{o} d
\end{gathered}
$$

\section{3 | MATERIAL AND METHOD}

\section{1 | Material}

The variable plate to be analyzed is three pieces of plates. The first is a solid plate with dimensions of length $2700 \mathrm{~mm}$, width $1800 \mathrm{~mm}$, and $140 \mathrm{~mm}$ symbolized by PB-1. The second plate is a hollow reinforced concrete slab with PVC as forming cavities with dimensions of length $2700 \mathrm{~mm}$, width $1800 \mathrm{~mm}$, and thickness is $140 \mathrm{~mm}$, symbolized by PB-2, and the last hollow reinforced concrete slab with PVC as forming cavities with dimensions of length is $2700 \mathrm{~mm}$, width $1800 \mathrm{~mm}$ and $159 \mathrm{~mm}$ thickness premises symbolized by PB-3. Each cavity PVC used $760 \mathrm{~mm}$ diameter, and all plates use steel reinforcement diameter of $8 \mathrm{~mm}$ with $100 \mathrm{~mm}$ spacing between the rebar. Details of the test specimen in this study can be seen in Table 3 .

Details design of a solid plate with dimensions of length $2700 \mathrm{~mm}$, width $1800 \mathrm{~mm}$, and thickness is $140 \mathrm{~mm}$ can be seen in Figure 3 The second plate is a hollow reinforced concrete slab with PVC as forming cavities with a thickness of $140 \mathrm{~mm}$ can be seen in Figure 4 and the last hollow reinforced concrete slab with PVC as forming cavities with a thickness of $159 \mathrm{~mm}$ in Figure 5

The analysis was conducted consisting of several stages depicted in the flowchart of Figure 6

The initial stage of this first analysis is a preparatory study which includes the formulation of the issues to be analyzed. Then the next stage is to determine and design the dimensions, including the quality of materials to be used for analysis. In this analysis, it is assumed specimen with a riveted joint support along all four sides. Simulation testing is a test plate with simulated bidirectional distributed load ${ }^{[7]}$. Analysis to calculate the flexural strength of the plate using the Navier deflection and calculating the shear strength using SNI 03-2847-2019 [8. 


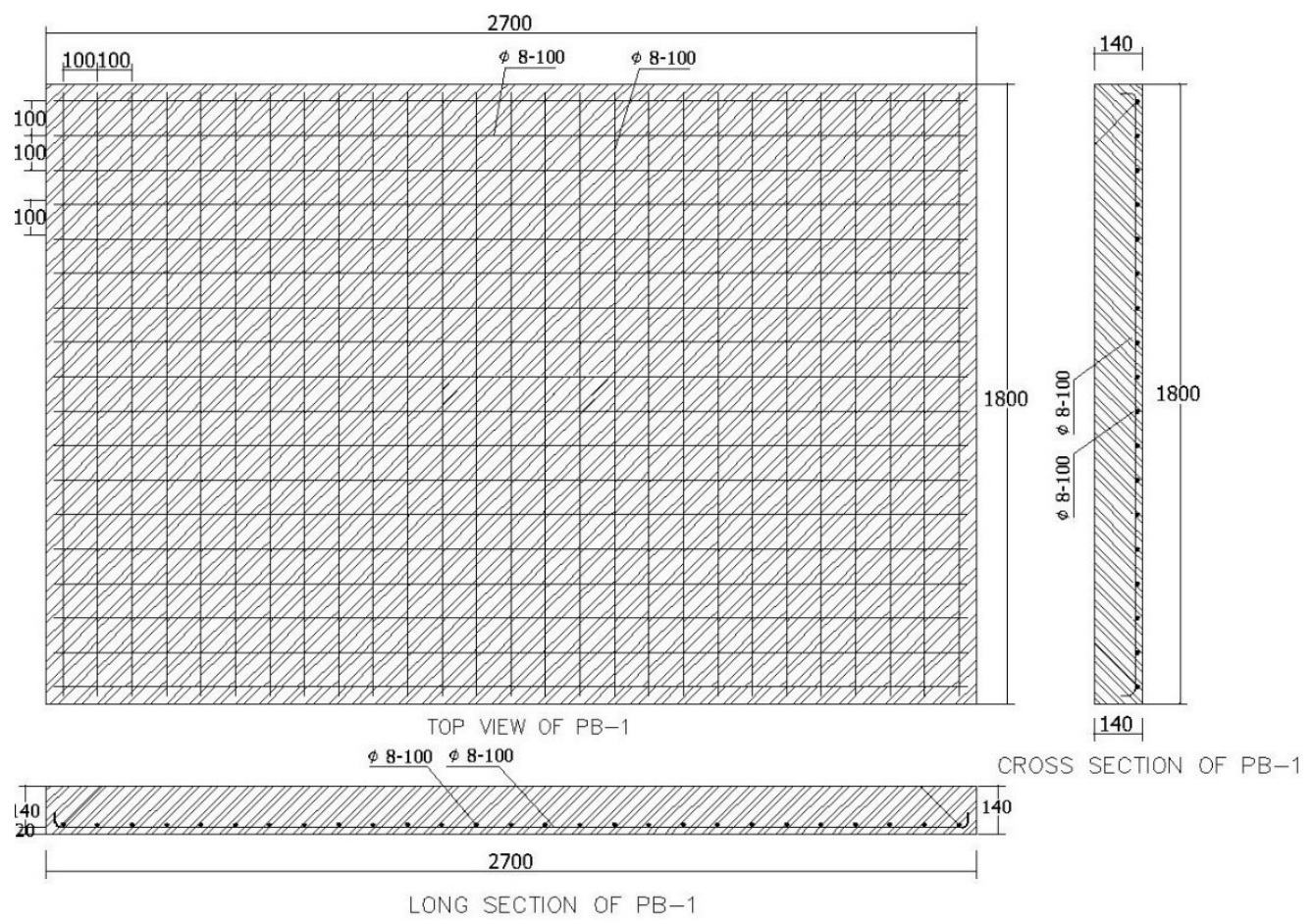

FIGURE 3 The design of solid plate (PB-1).

TABLE 5 The flexural strength analysis.

\begin{tabular}{lccccc}
\hline Plate & $\begin{array}{c}\mathbf{A s} \\
\left(\mathrm{mm}^{2}\right)\end{array}$ & $d(\mathbf{m m})$ & $\begin{array}{c}\boldsymbol{M n} \\
(\mathbf{k N m})\end{array}$ & $\rho(\mathbf{k N})$ & $\begin{array}{c}\text { Percentage } \\
(\text { To PB-1) }\end{array}$ \\
\hline PB-1 & 453416 & 112.39 & 17.076 & 328.175 & 100.000 \\
PB-2 & 453.416 & 112.39 & 17.076 & 329.624 & 100.465 \\
PB-3 & 453.416 & 131.39 & 20.048 & 387.184 & 117.999 \\
\hline
\end{tabular}

\section{4 | RESULTS AND DISCUSSION}

The analysis of self-weight calculation plates per square meter is obtained as in Table 4

\section{1 | Flexural Strenght Plate}

Flexural strength analysis conducted for the flexural strength of each test specimen consisted of a solid reinforced concrete slab as a comparison of two hollow reinforced concrete slab PVC. Using analysis of plate bending strength in both directions to get the maximum load moment coefficients obtained using the method of maximum bending load values as in Table 5

The maximum load capacity on a massive plate (PB-1) amounted to $328.175 \mathrm{kN}$. In comparison, the maximum capacity of the hollow reinforced concrete slab $14 \mathrm{~cm}$ (PB-2) amounted to $329.624 \mathrm{kN}$, and a maximum load capacity of hollow reinforced concrete slab PVC thickness Of 15.9 (PB-3) amounted to $387.184 \mathrm{kN}$, a result compare of the analysis on each plate can be seen in Figure 7

\section{2 | Deflection of Plate}

Deflection in the middle plate was analyzed using the Navier method wherein the plate in linear elastic condition so that deflection was calculated before the first crack load. The result of the analysis using the Navier method is shown in Table 6 


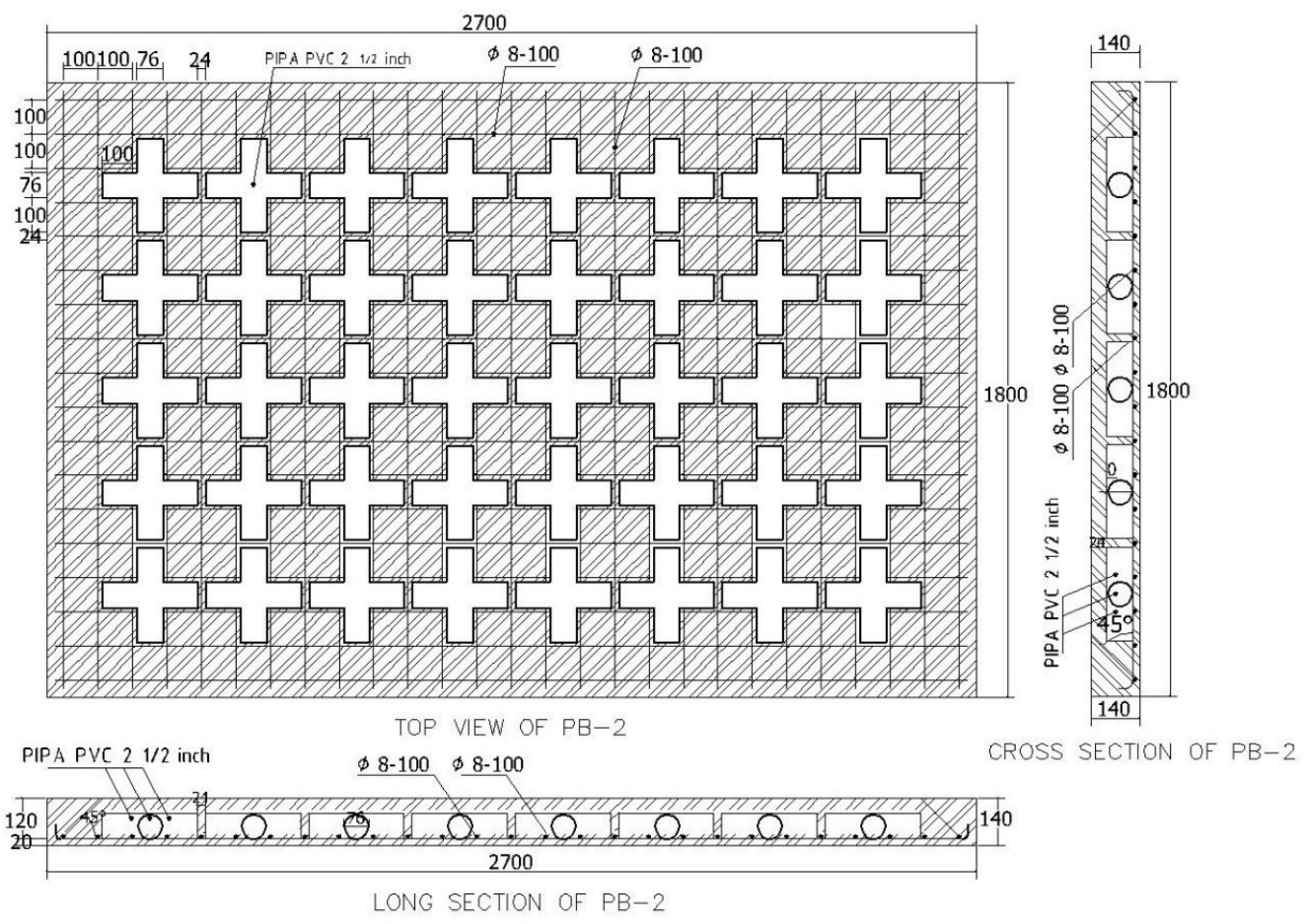

FIGURE 4 The design of hollow reinforced concrete slab (PB-2).

TABLE 6 The deflections with navier method.

\begin{tabular}{lcccc}
\hline Plate & $\begin{array}{c}\text { Center of } \\
\text { Gravity y } \\
(\mathbf{m m})\end{array}$ & $\begin{array}{c}\text { Inertia } \\
\text { Moement } \\
\left(\mathrm{mm}^{4}\right)\end{array}$ & $\begin{array}{c}\text { Crack } \\
\text { Moment } \\
(\mathbf{k N m})\end{array}$ & $\begin{array}{c}\text { Deflection } \\
(\mathbf{m m})\end{array}$ \\
\hline PB-1 & 68.838 & 319700750.460 & 17.356 & 0.09480 \\
PB-2 & 68.743 & 311450000.000 & 16.931 & 0.33952 \\
PB-3 & 78.001 & 51152646.925 & 24.507 & 0.04267 \\
\hline
\end{tabular}

Deflection when the first crack in the reinforcement concrete massive slab (PB-1) greater than deflection hollow reinforced concrete slab (PB-3), but deflection hollow reinforced concrete slab (PB-2) greater than deflection in reinforcement concrete massive slab (PB-1). Results of the calculation shown in Figure 8

\section{3 | Shear Force Plate}

The main difference between a hollow reinforced concrete slab with a massive plate is the resistance of shear force. The diminishing volume of concrete would reduce the shear of forces. Hence a hollow reinforced concrete slab is in a critical shear area with a minimum cross-section or on a cross-section that has a maximum cavity. Shear forces analysis of hollow reinforced concrete slab in DIN 1045-1 based on the area between the ball, while the area above and below the ball is not included, illustrated in Figure 9.

Force shear plates can be analyzed if known around the loading area of the load area. By explaining the critical areas of the hollow core slab above, it approaches to determine the shear region in areas along the middle of the ball, on the edge of the plate line of the ball. Comparison of the result of force shear between reinforcement concrete massive (PB-1), hollow reinforced concrete slab (PB-2), and hollow reinforced concrete slab (PB-3) can be seen in Table 7 The comparative shear force between PB-1, PB-2, and PB-3 is shown in Figure 10 


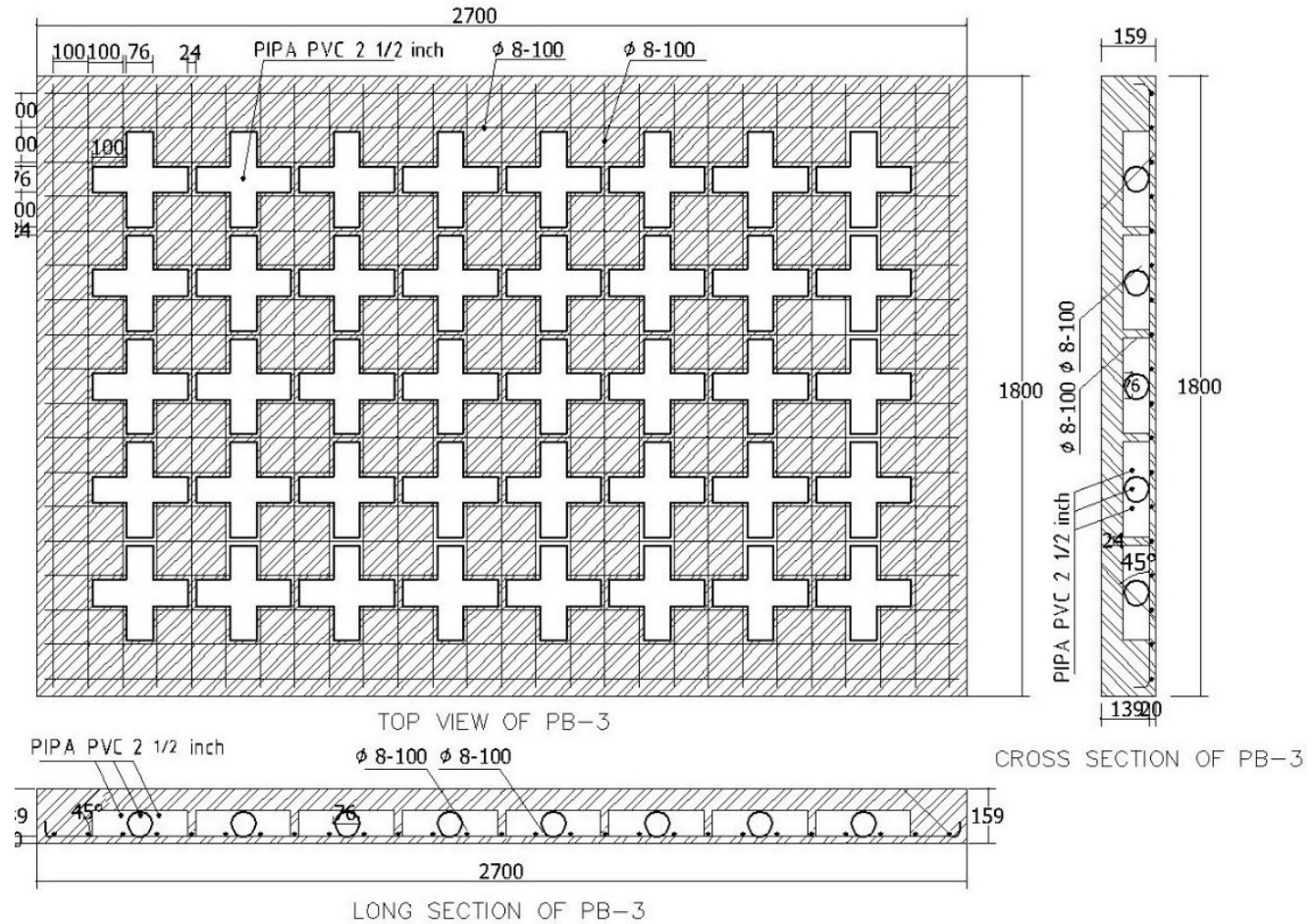

FIGURE 5 The design of hollow reinforced concrete slab (PB-3).

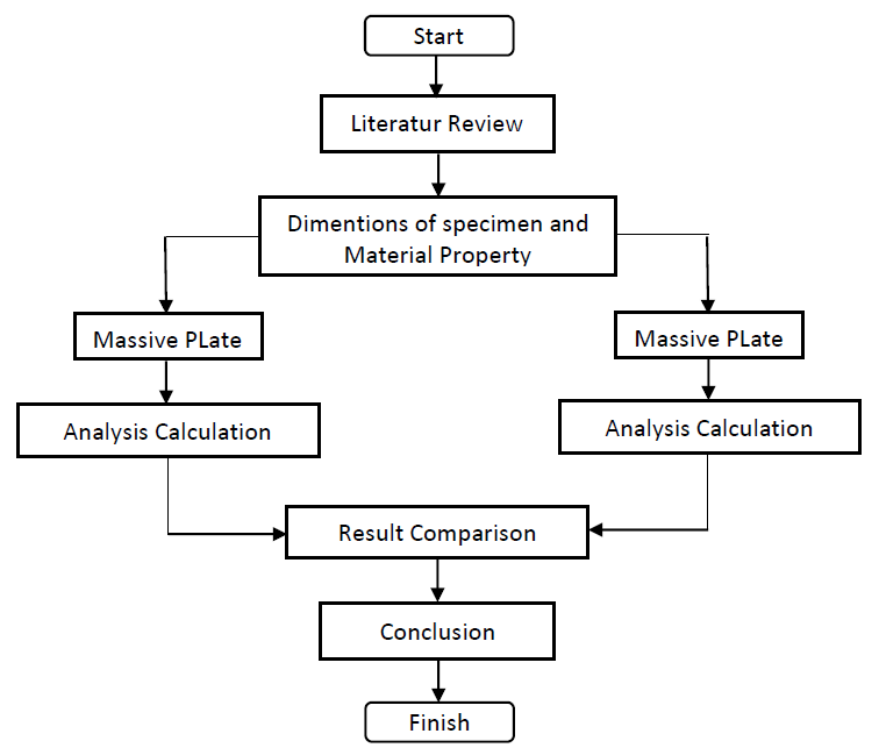

FIGURE 6 Research flowchart.

\section{5 | CONCLUSION}

Based on the analysis that has been done, we came up with three conclusions. First, the maximum load capacity on a massive reinforced concrete slab of $328.175 \mathrm{kN}$, while the maximum capacity load in a hollow reinforced concrete slab is $14 \mathrm{~cm}$ and 15.9 $\mathrm{cm}$ thick, respectively $329.624387 .184 \mathrm{kN}$. This suggests that the reduced volume of concrete on a hollow reinforced concrete slab of $14 \mathrm{~cm}$ has little effect on the strong bending. While on hollow reinforced concrete slab $15.9 \mathrm{~cm}$, increasing effective 


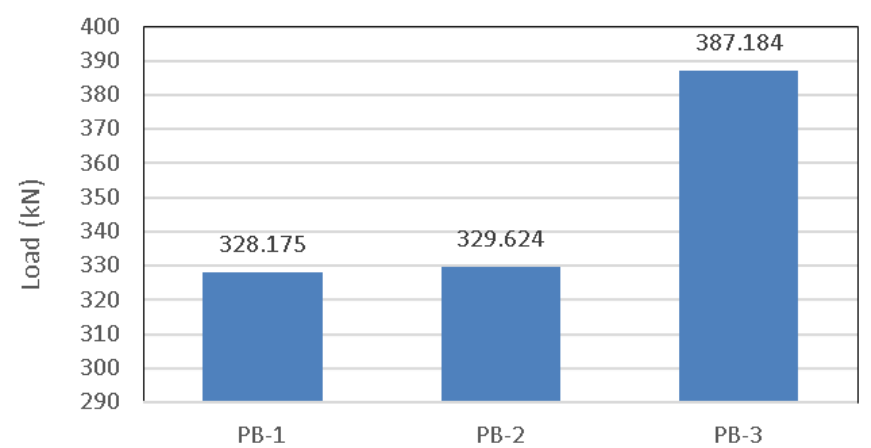

FIGURE 7 The flexural loag.

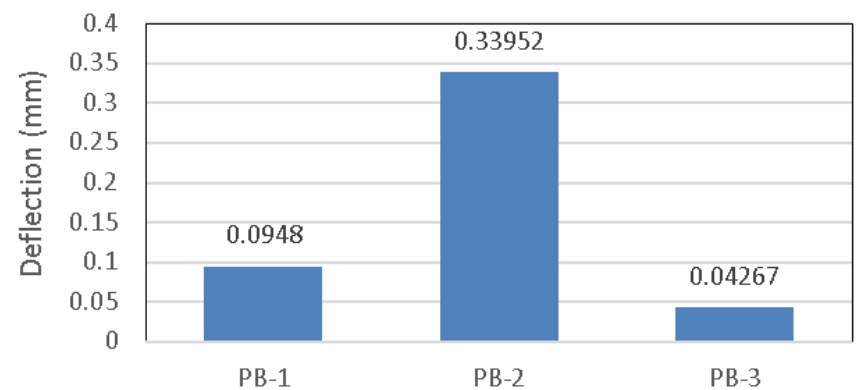

FIGURE 8 The deflection using navier method.

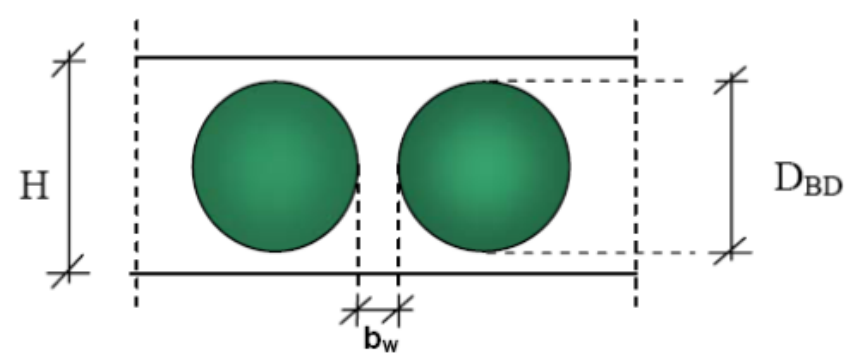

FIGURE 9 The shear cross section in hollow core slab.

high impact plates increases the maximum capacity load. Second, the deflection whenever the initial crack in the middle span amid massive reinforced concrete slab of $0.0948 \mathrm{~mm}$ was lower than the deflection of the hollow reinforced concrete slab $14 \mathrm{~cm}$ of 0.33952 , but higher than hollow reinforced concrete slab $15.9 \mathrm{~cm}$ of $0.04267 \mathrm{~mm}$. Third, massive reinforced concrete slab capable of holding a larger shear strength of $965.908 \mathrm{kN}$ compared to hollow reinforced concrete slab $14 \mathrm{~cm}$ of $231.818 \mathrm{kN}$ and hollow reinforced concrete slab $15.9 \mathrm{~cm}$ of $281.429 \mathrm{kN}$. This shows that the hollow reinforced concrete slab prone to cracking shear.

Given the result, there are two research directions that can be pursued. First, researchers need to analyze variation of concrete volume cavity. Thus, researchers need to obtain hollow concrete slab with self-weight optimum again the planned load. Second, researchers need to study the influence of the strength of PVC pipe on the power structure of the plate. 
TABLE 7 The shear forces analysis.

\begin{tabular}{cccccc}
\hline Plate & $\begin{array}{c}\text { Effective Plate } \\
\text { Thickness }(\mathbf{m m})\end{array}$ & $\begin{array}{c}\text { Long Analysis } \\
(\mathbf{m m})\end{array}$ & $\begin{array}{c}\text { Wide Analysis } \\
(\mathbf{m m})\end{array}$ & $\begin{array}{c}\text { Shear Foces } \\
(\mathbf{k N})\end{array}$ & $\begin{array}{c}\text { Percentage } \\
(\boldsymbol{\%})\end{array}$ \\
\hline PB-1 & 112.39 & 2487.61 & 1237.61 & 965.908 & 100 \\
PB-2 & 112.39 & 2487.61 & 1237.61 & 231.818 & 24.002 \\
PB-3 & 131.39 & 2487.61 & 1237.61 & 281.429 & 29.139 \\
\hline
\end{tabular}

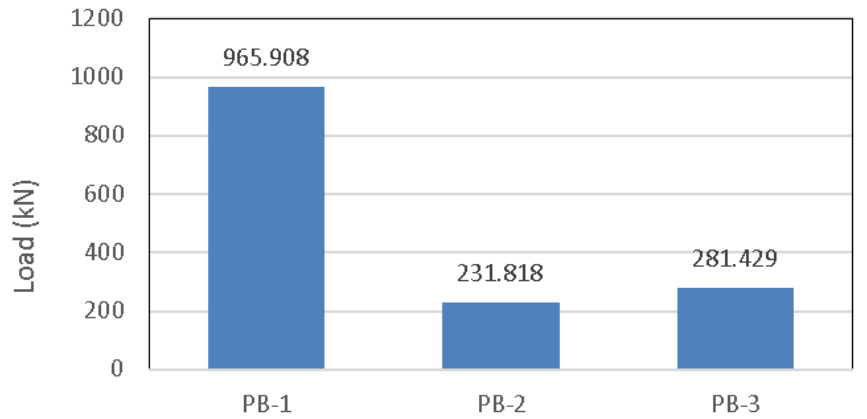

FIGURE 10 The shear forces of the plate.

\section{References}

1. Jati DG. Flexible analysis of reinforced concrete plate in one direction using non linear element method. Konferensi Nasional Teknik Sipil 2013;7:S77-S84.

2. Aldejohann M, Schenellenbach-Held M. Investigations on the shear capacity of biaxial hollow slabs. Federation Internationale du Betton; 2004.

3. Prabhu Teja P, Vijay Kumar P, Anusha S, Mounika CH, Saha P. Structural behavior of bubble deck slab. IEEE-International Conference on Advances in Engineering, Science and Management, ICAESM-2012 2012;p. 383-388.

4. Soeharno A. Bending and Shearing Behavior of One-Way Hollow Reinforced Concrete Plates with Cast Concrete in Place. $\mathrm{PhD}$ thesis, Gadjah Mada University; 2009.

5. Schnellenbach-Held M, Pfeffer K. Punching behavior of biaxial hollow slabs. Cements and Concrete Composites 2002;24(6):551-556.

6. Mama BO, Nwoji CU, Ike CC, Onah HN. Analysis of Simply Supported Rectangular Kirchhoff Plates by the Finite Fourier Sine Transform Method. International Journal of Advanced Engineering Research and Science 2017;4(3):285-291.

7. E2322-03 A. Standard Test Method for Conducting Transverse and Concentrated Load Tests on Panels used in Floor and Roof Construction. West Conshohocken, PA: ASTM International; 2015. http://www.astm.org

8. Public Work Department. Standar Nasional Indonesia 2847:2019 Procedure for Calculation of Reinforced Concrete Structures for Buildings. Jakarta, Indonesia: Badan Standardisasi Nasional; 2019.

How to cite this article: Atmadja W.M.T., Parung H., Irmawati R., Amiruddin A., (2020), Flexural and Shear Behaviour of Reinforced Concrete Slab with Pvc Pipe as A Cavity Forming in Two-Way System, IPTEK The Journal of Technology and Science, 31(3):364-372. 